https://doi.org/10.24101/logos.2020.56

Gauta 20200520

ALEKSANDR SAUTKIN

Murmansko Arkties valstybinis universitetas, Rusija

Murmansk Arctic State University, Russia

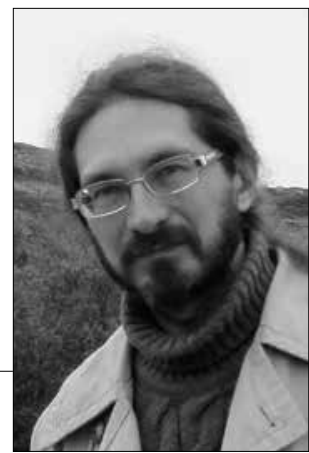

\title{
AŠTUNTOJO IR DEVINTOJO DEŠIMTMEČIŲ KRAŠTOVAIZDŽIO ISIVAIZDAVIMAS: MOKSLINĖS FANTASTIKOS TAPYBA KAIP TECHNOKRATINĖS UTOPIJOS RAIŠKA
}

Landscape Imagination of the 1970s and 80s: Sci-Fi Painting as a Manifestation of the Technocratic Utopia ${ }^{1}$

\author{
SUMMARY
}

The article discusses the development of sci-fi landscape painting in late Soviet art. The article is based on an analysis of the popular science magazine, "Technics for the Youth", contributed by participants from USSR and other socialistic countries. The genre is a synthesis of official communist ideology with its utopian technocratism and some ideas of the philosophy of cosmism, representing the anticipation of the imminent future of humanity as it is characterized by overcoming the spontaneous forces of nature and the arrangement of man's earthly and extraterrestrial environment. The methodological approach of G. Durand allows us to interpret this cultural phenomenon of imaginary landscapes in line with the "diurnal" mode of imagination.

\section{SANTRAUKA}

Remiantis populiaraus mokslo žurnalo "Technika jaunimui“ pateiktomis dailès kūrinių publikacijomis, kurias sukūre SSRS ir kitų socialistinių šalių piliečiai, straipsnyje aptariama mokslinės fantastikos kraštovaizdžio tapybos žanro plètra vèlyvajame sovietiniame mene. Tai žanras, kuris vaizduoja oficialiosios komunistinès ideologijos su jos utopiniu technokratiškumu ir kai kurių kosmizmo filosofijos idèju sintezę. Perteikiamas neišvengiamas žmonijos ateities vaizdas, kuriam būdingas spontaniškų gamtos jejgu ịveikimas ir žmogaus žemiškos bei nežemiškos aplinkos išsidèstymas. G. Durando metodologija leidžia aiškinti ši kultūrinį įsivaizduojamų peizažų reiškinị pasitelkiant "dieninį" vaizduotės būdą. 


\section{INTRODUCTION}

We tend to view the "landscape" in the spirit of Denis E. Cosgrove as "a way of seeing the world." The landscape cannot be reduced to only visible material elements of the environment, natural and affected by human impact, the landscape idea itself is an attitude included into a complex network of social relations, always historically determined and going beyond the limits of economic and class configurations - the relations arising in connection with symbolic production (of meanings, values, etc.)

Cosgrove also emphasized this point: "But symbolic production may also relate to transhistorical and transcultural, unalienated human experiences and concerns, those that derive from our shared human physiology, our experience of birth, death, childhood, sexual experience and so on" (Cosgrove 1998: 96). This "transhistorical" component is something that has inherent value and can hardly be reduced to other factors, acting as existential given.

The landscape is something visible or, at least, possible to be imagined as visible, even if it is represented verbally: be it Dante's Inferno spaces, or oneiric landscapes from Lovecraft's stories. Imagination is an indispensable element of any landscape, but in this article, we intend to focus precisely on those landscapes that represent imaginative creations and are represented by visual images.

We interpret imagination not only and not so much as fantasy, i.e. as the ability to generate images that are not given to us in the presence, but rather as a special element of the human being, providing a link between the physical level of being with symbolic and even supersensible levels. Following Gilbert Durand, we consider imagination not as a shadow of things, but as a powerful generating force acting as a mediator between the biological and the social. Durand wrote that the symbol is always the product of bio-psychic imperatives, carried out following the requirements of the environment (Durand 1992: 39).

An analysis of imaginary landscapes and ways of representing them in visual arts allows us to comprehend certain key orientations of the consciousness of a particular epoch. Even more than that: we can postulate that conscious attitudes have an unconscious element as their basis. This is what Durand calls "le fantastique transcendantal" what determines the essence and configuration of those images through which people model their landscape views. Some of them are deduced from the general aesthetic premises of a particular epoch, but in their basis, they go back to archetypal schemes and matrices of imagination.

Using such research strategies as mythocritique and mythanalyse, by means of concrete, particular images, one can get access to the myth as a dynamic system of symbols, archetypes, and schemes realized in these images, and thus the deep meaning of the image representations can be understood. The meaning of social phenomena represented in images can be deduced from an area that Durand calls imaginary (l'imaginaire). 


\section{THE CREATION OF SCI-FI PAINTING AT THE INTERSECTION OF SCIENCE AND ART}

Considering the landscape imagination of the 1970s and 80s in the Central and Eastern European areas, we drew attention to such a peculiar phenomenon as the "Time - Space - Human" contest of sci-fi painting, regularly conducted by the well-known Soviet magazine "Tekhnika - Molodezhi" ("Technics for the Youth") published in a circulation of 1 million 700 thousand copies. The magazine was contributed by many scientists, writers, and artists from Poland, Hungary, the Czech Republic, the German Democratic Republic, and Bulgaria.

The magazine, founded in 1933, was one of the most important popular science magazines in the former USSR and is still published. Similar periodicals for young people existed in other countries of the former socialist camp. In addition to the main body of materials devoted to the popularization of science and technology, these magazines published science fiction and taking into account the almost complete absence of specialized sci-fi magazines in most of these countries, one can agree with the opinion of Mike Ashley, who writes that "these science and technology magazines effectively played the role of ersatz genre magazines in the Soviet bloc countries for quite some time" (Ashley 2016: 301).

For the first time, the contest was announced in the February issue of the magazine in 1977. The formation of socialist sci-fi painting dates back to earlier: exhibitions on space and futuristic topics were held in the late 1960s, and at the opening of the "Cosmos of Tomorrow" exhibition (1974) the new genre was officially named "science fiction painting" (Salakhov 1974: 35).

The first round of the "Time - Space Human" contest was completed in 1980: the December issue summed up the results, which showed a great interest in sci-fi painting. Over the past four years since the beginning of the contest, more than 1,000 artworks had been submitted to the editorial board, 200 of which had been published, and 500 had been selected for special collections, including a mobile exhibition of the same name, accompanied by lectures on the new genre. Among the participants of the competition were artists from Bulgaria, Poland, Hungary, Czechoslovakia, Mongolia, Cuba, Yugoslavia.

Human interaction with space, as well as the preservation and transformation of the landscape environment were declared as the main themes for the contest works. Remarkable is the very fact of redirecting the utopian-technocratic discourse into the visual sphere, as well as the substantiation of the separate genre (Editorial. 1977: 15).

The work of artistic fantasy was interpreted as an attempt to look into the future and visually present some variants of the development of mankind. The permanent author of the journal Ivan Papanov wrote: "Fantastic painting is science and art at the same time, organically merging these two principles" (Papanov 1977b: 47). 
One of the drawings submitted to the contest belonged to the doctor of technical sciences, professor, and the winner of the State Prize of the USSR Georgy Pokrovsky and illustrated his idea of using water reserves in mountain glaciers for the needs of the national economy. Pokrovsky possessed the talent of an artist and created works of art in the proper sense of the word (Alyabyev 1979: 12). The paintings of cosmonaut Alexei Leonov, who in 1979 received the prestigious Lenin Komsomol Prize for the art album "Man and the Universe" (together with Andrei Sokolov), certainly reflected the professional knowledge of the cosmonaut.

The propagation of science and technical creativity through the means of visual art and the fusion of scientific and artistic intentions is very characteristic of that particular ideology in which science becomes a titanic power that transforms the worlds, nearest and far.

The best artworks presented as part of the contest were published in a special section accompanied by texts somehow related to scientific problems or technical achievements. Although those accompanying texts had just a supporting function, they could be compared with the genre of the classic ode at the level of pathetic. They verbally complemented fully self-sufficient images submitted for the contest, while the remaining images in the magazine (there were many of them and they were quite colorful) served as illustrations for text materials.

\section{GEOCOSMISM AS A DOMINANT OF LANDSCAPE IMAGINATION}

Spatial images include terrestrial and oceanic landscapes as well as extraterrestrial spaces. Cosmic landscapes serve to broaden the notion of those areas of the universe that are becoming accessible to man and can be brought under his control.

It is not surprising that of the first ten publications in the "Time - Space - Human" contest rubric (№ № 3-12, 1977), nine were related to outer space themes. In 1977, the 20th anniversary of the launch of the first artificial Earth satellite was celebrated. Besides the memorable date, it should be pointed out that outer space had already been considered as an integral part of the natural environment of mankind. This idea was actively broadcasted to the mass consciousness, and this "obsession with the cosmos" is very typical for the 1970s, while for nowaday mass consciousness the idea that 'the cosmos is quite near' is perhaps less obvious and causes not such a great emotional response.

Nevertheless, at the level of scientific reflection of ecological consciousness, this idea is quite obvious. So, Alice Gorman writes: "With the launch of Sputnik 1 in 1957, human interaction with space was no longer confined to the imaginary realm. In the last 60 years, parts of interplanetary space have become filled with human material. <...> No longer the last wilderness or the final frontier, interplanetary space can be seen as a cultural land- 
scape forged by the organic interaction of the space environment and human material culture" (Gorman 2005: 86).

This theme of "geocosmism" and "space ecology" was being actively introduced by the magazine in the 1970s, albeit at a rather schematic level of popular scientific publications for young people. V. Vernadsky stated that humanity gradually becomes a geological force; the already mentioned Ivan Papanov wrote, paraphrasing, that "humanity gradually becomes a cosmic force. Helping to better understand the consequences of what is happening on the planet, the 'third dimension,' outer space, is also a human environment. Scientific and social progress is further bringing mankind to cosmic orbits, and the volume of our planet already seems to us rather limited." (Papanov 1977a: 25)

The texts accompanying the published artworks are either lyrical essays in their pure form or essays interspersed with discussions of specific and technical ideas correlating with the reproductions of paintings and drawings in one way or another. The texts of both types, as a rule, are characterized by an extremely sublime tone and full of the pathos of a breakthrough to new worlds and life horizons, of mankind's awareness of its increasing power. Methods of retrospection are also used a lot, such as the references to the past; the role of individual outstanding minds is often recalled and the meaning of imagination is emphasized.

Here is an example from an article (Papanov 1977c: 46) which begins as "The great visionaries of the past had talked about the distant starry roads of mankind long before the dream of space flights be-

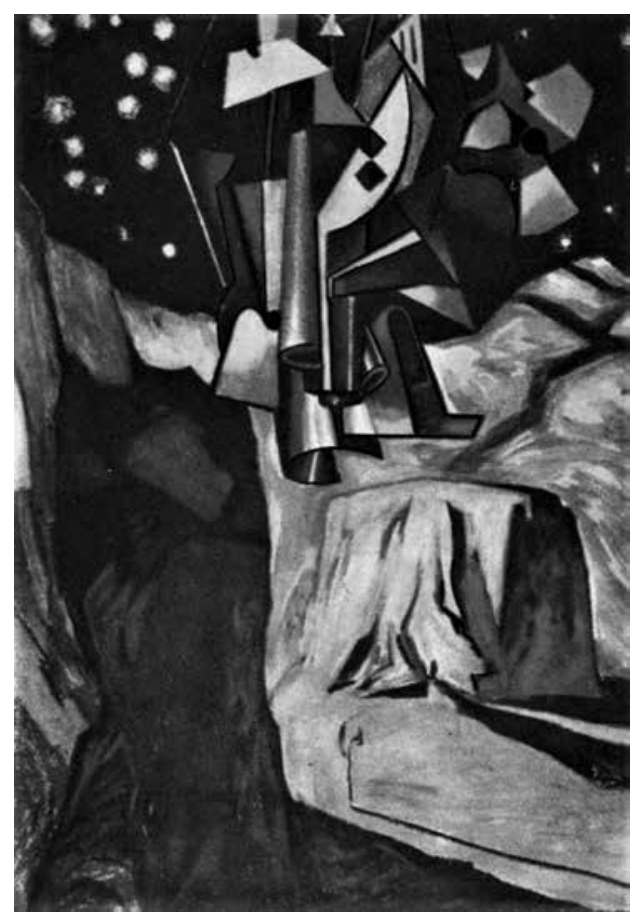

E. Bukreev The First Sprout (Tekhnika - molodezhi, 1977, № 8)

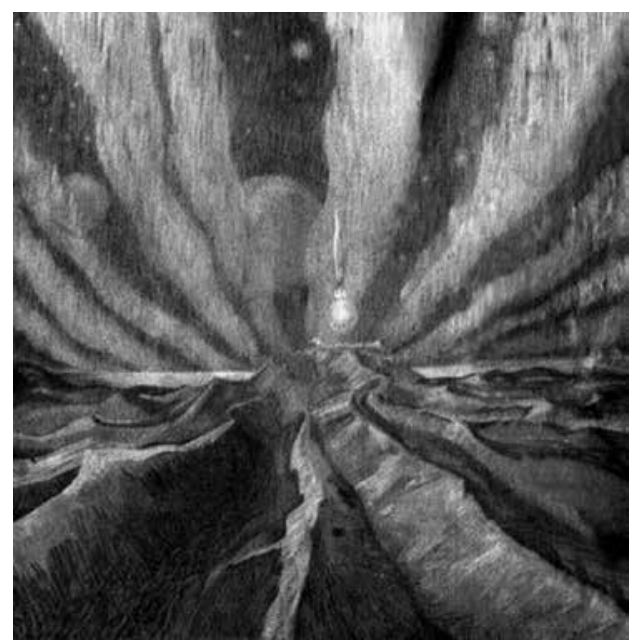

E. Bukreev The Southernmost Cosmodrome (Tekhnika - molodezhi, 1977, № 8)

came a reality," - further there is a story about some ideas of K. Tsiolkovsky - and then a discussion of some modern ideas 
related to the expansion of the habitable space of the Solar System and the use of the radiant energy of the Sun.

In other words, the accompanying articles are mostly a kind of a popularscience commentary on published artworks. As a rule, one or several scientific and technical details are emphasized in the picture, around which the whole text is constructed. For example, the text of Elena Preobrazhenskaya "Wind of Star Wanderings" (1977: 6-7), accompanying the reproductions of two paintings by Evgeny Bukreev.

The first picture, titled "The southernmost cosmodrome," is followed by a short-write, in the already described enthusiastic-romantic style, about the development of Antarctica. And although cosmodromes have not yet been built on this continent, man has been making efforts to small accomplishments: the article tells about the construction of a greenhouse for growing vegetables (with a description of some technical details) on the Soviet Antarctic station Novolazarevskaya, and this fact is further compared with the idea of transferring life to other planets, possible in the future. This second theme is in tune with another picture by the same artist E. Bukreev "The First Sprout," which depicts the sprout of a plant on a distant planet with a departing spacecraft above it.

This "geocosmic" attitude, being projected onto the terrestrial space, defines this latter as a zone of expanding and intensifying human control over spontaneous processes. On the one hand, it is expressed in the images of radical climatic and territorial transformations (tropical gardens in Arctic latitudes, multi-level urban landscapes, etc.), and on the other hand in attempts to reconcile the artificial rhythm of civilization with the natural rhythms, but precisely using scientific and technical power. Perhaps, not even adjusting mankind to the rhythm of nature, but rather rebuilding nature for mankind.

The study of the submitted artworks reveals a combination of various elements: the obvious influence of the official communist ideology, the ideas of technocracy, the philosophy of cosmism, ecophilosophy, etc. The deep archetypal nature and social functions of this mix need to be explored.

In this complex of ideological influences, especially significant is the impulse from the philosophy of Russian cosmism with its specific synthesis of scientific and technological optimism and ecological holism, which often assumed religious (and extremely unorthodox) forms (see: Young 2012). It is possible to recall at least the ideas of Nikolai Fedorov (1829-1903) about the physical resurrection of all the dead by the forces of positive science. Nature, according to Fedorov, must turn from a "temporary enemy" into a "permanent friend," but this is possible only with active and purposeful human intervention in the course of natural processes.

It is worth mentioning here the wellknown poem of Nikolai Zabolotsky, who was under the influence of both Nikolai Fedorov and Konstantin Tsiolkovsky:

I'm not looking for harmony in nature.

So far, alas, I have not noticed

the reasonable proportion of the principles, either in the depths of the rocks or the clear firmament. 


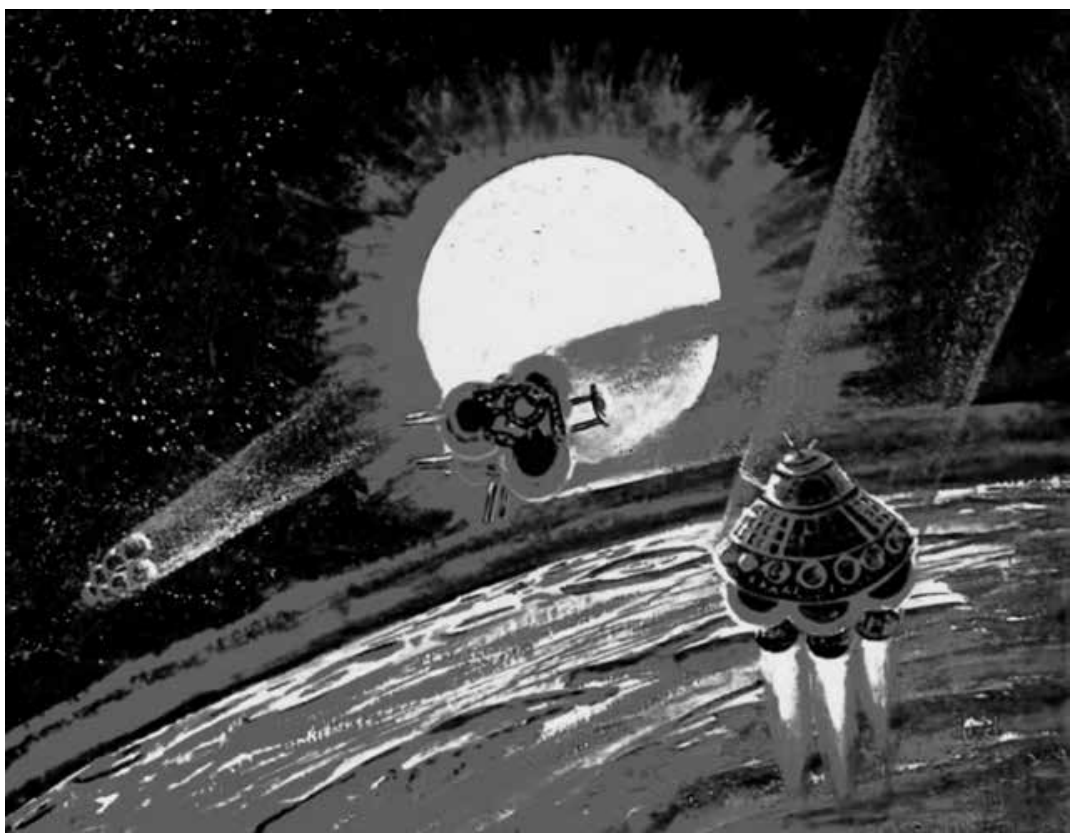

G. Tishenko Landing on Mercury (Tekhnika - Molodezhi, 1977, № 9)

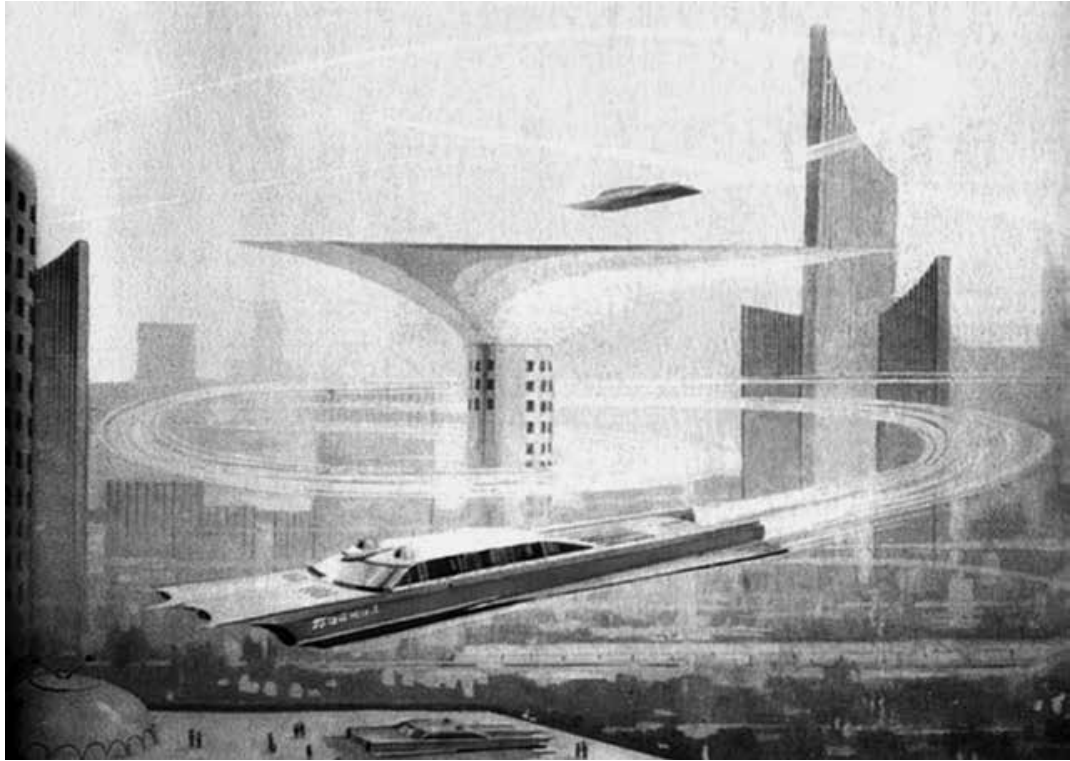

V. Shikhov Siberian Motive (Tekhnika - molodezhi, 1978, № 4)

The author of the article expresses his sincere gratitude to the editor-in-chief of the magazine "Tekhnika - Molodezhi" ("Technics for the Youth") Aleksandr Perevozchikov for the kind permission to reproduce some paintings that participated in the competition "Time - Space - Man". The modern version of the magazine can be found on the official website: www.technicamolodezhi.ru 
Traditional poetic chanting of nature is turned inside out: there is no harmony in nature, it is only an unconscious and senseless play of destructive forces. Nature can attain harmony only by being transformed by man:

It dreams of a brilliant shaft of a turbine,

And the rhythmical sound of reasonable labor..

At the end of the poem Nature is likened to a "mad, but loving mother," who only in her son (human) and through him acquires meaningfulness and fullness of being.

Not to submit to nature, but to give it the opportunity of becoming something other than "the everlasting press, connecting death and being" (an expression from Zabolotsky's poem "Lodeyni-

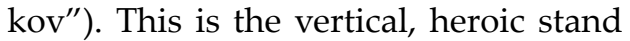
of the confrontation to death, spread in Nature as its integral part. Overcoming death, ordering Chaos - this is the task for late-Soviet sci-fi writers and popularizers. The goal is to take control and reconstruct not only the terrestrial space but also of distant planets in the future. A new term, "terraforming," was constructed and used in the meaning of "the alteration of the planets to conditions favorable for life.'

The general orientation of the landscape imagination in the sci-fi painting clearly tends toward the philosophy of Russian cosmism. In the accompanying texts, there are references to Tsiolkovsky and Vernadsky (most often), as well as N. Fedorov, A. Chizhevsky, and Teilhard de Chardin. Of course, religious and other non-materialistic components of Russian cosmism (such as Tsiolkovsky's panpsychism) were eliminated for ideological reasons. Nevertheless, one can note the attraction of a part of the late Soviet intelligentsia to a kind of New Age worldview that combines scientific ideas and non-canonic spirituality.

The Polish writer Konrad Fiałkowski in his essay "The Model of Fictional Reality" published in "Technics for the Youth" (1977, No. 6) wrote that science fiction arose in a special climate of faith in the power of science which creates unpredictable values (Fiałkowski 1977: 50-51). It seems that this climate can be understood through the revealing of its fundamental archetypal bases.

V. Klenov writes about the striving of Soviet art to acquire "a single criterion of artistic and technical aesthetics" (Klenov 1979b: 7), that "Modernity has united the language of science and the language of art," and "technology allowed to peer into the unknown features of the universe and love them" (Klenov 1979a: 17; 16). Such an insistently held idea of a new synthesis of scientific, technical, and aesthetic dimensions indicates a new social imperative, which is reflected in the images of fantastic landscapes: it is a readiness to become the actor of a new heroic epic.

The same mood is revealed in sci-fi painting: we find the motive of aspiration upwards, the motive for the rupture of the habitual everyday existence, the visual images of a breakthrough, confrontation, struggle. Rising, straightening, ascension, according to G. Durand, are all correlates of the postural reflex underlying the diurnal mode. The scheme of rising, lifting, and vertical symbols are "axiomatic metaphors" of the diurnal, whose leading figure is the "hero." The rhetorical correspondence of heroic archetypes is the antithesis. This 
"heroic" mode of imagination seems to prevail in the landscape poetics of sci-fi art of late socialism, moreover, its scale is cosmic, transplanetary, even if we are talking about the transformation of proper terrestrial territories. It is significant that in the post-Soviet period, the themes of artworks under the heading "Time Space - Human" become wider and more eclectic, going beyond the scope of science fiction itself. Soviet visual utopianism fragmented quite quickly, which obviously correlated with a change in leading archetypes.

\section{CONCLUSION}

Sci-fi painting, being a constant companion of sci-fi literature in the form of illustrations, at a certain moment, gains independence. In the 1970s, it was institutionalized into a separate genre area, and the popular science magazine "Technics for the Youth" played a significant role in this process in collaboration with similar periodicals of the socialist countries. This genre was a vivid exponent of the diurnal

\section{References}

Alyabyev, V. 1979. Mechtoy okrylyaya nauku [Dream inspiring science], Tekhnika-Molodezhi, 10: 12-13.

Ashley, M. 2016. Science-Fiction Rebels: The Story of the Science-Fiction Magazines from 1981 to 1990. Liverpool: Liverpool University Press.

Cosgrove, D. E. 1998. Social Formation and Symbolic Landscape. Wisconsin: The University of Wisconsin Press.

Durand, G. 1992. Les structures anthropologiques de l'imaginaire. Paris: Dunod.

Fiałkowski, K. 1977. The Model of Fictional Reality, Tekhnika-Molodezhi, 6: 50-51.

Gorman, A. 2005. The cultural landscape of interplanetary space, Journal of Social Archaeology, 5(1): 85-107.

Klenov, V. 1979a. Proniknoveniye [Penetration], Tekhnika-Molodezhi, 2: 16-17.

\section{Endnotes}

1 The results of the research were presented at the international conference "Cultural Landscapes in Central and Eastern Europe after archetypal tendency embodied in impressive images of the large-scale reorganization of the external environment, that is why late Soviet sci-fi painting can be considered the leading means of expressing the titanic spirit of techno-utopia while the influence of the philosophy of cosmism introduced the elements of "space ecology" and the idea of the scientific regulation of natural processes.

Klenov, V. 1979b. Sotvorchestvo s vekom [Co-creation with the Century], Tekhnika-Molodezhi, 9: 6-7.

Papanov, I. 1977a. U istokov legendy [Origins of the legend], Tekhnika - Molodezhi, 11: 24-25.

Papanov, I. 1977b. Vernost' mechte [Fidelity to a dream], Tekhnika - Molodezhi, 6: 46-47.

Papanov, I. 1977c. Shagi v nevedomoye [Steps into the unknown], Tekhnika - Molodezhi, 9: 46-49.

Preobrazhenskaya, E. 1977. Veter zvezdnykh stranstviy [Wind of Star Wanderings], TekhnikaMolodezhi, 8: 6-7.

Salakhov, T. 1974. Otkrytie novogo zhanra [Discovering a new genre], Tekhnika - Molodezhi, 6: 35.

Editorial. 1977. The contest "Time - Space - Human" is announced, Tekhnika-Molodezhi, 2: 15.

Young, G. M. 2012. The Russian Cosmists: The Esoteric Futurism of Nikolai Fedorov and His Followers. New York: Oxford University Press.

World War II and the Collapse of Communism" (Wrocław, Poland, 19-21 September 2018). 